\title{
Rola Frontex w zarządzaniu przestrzenią wolności, bezpieczeństwa i sprawiedliwości UE
}

\begin{abstract}
Streszczenie: Celem artykułu jest horyzontalna i funkcjonalna analiza umiejscowienia agencji Frontex w systemie instytucjonalnym UE oraz wskazanie jej znaczenia w tworzącym się ponadnarodowym systemie zabezpieczania granic. Artykuł jest próbą odpowiedzi na pytanie, czy Frontex jest nowym rodzajem instrumentu zarządzania przestrzenią wolności, bezpieczeństwa i sprawiedliwości UE?

W pracy wykorzystano metody jakościowe, a za źródło informacji posłużyła analiza treści dokumentów i literatury przedmiotu.

W artykule znajdują się informacje o roli i specyfice agencji ponadnarodowych, znaczeniu Frontex i usytuowania w strukturze instytucjonalnej UE, jak również o utworzonych instrumentach realizacji celów agencji tj. Eurosur i IBM. Dyskusji poddano także aspekt przenikania się sfery krajowej i ponadnarodowej w omawianym aspekcie PWBiS.

Artykuł dowodzi, że pozytywnie należy zweryfikować założenie, że to tworzone na poziomie ponadnarodowym narzędzia służące realizacji celów Frontex sprzyjają procesowi uwspólnotowienia systemu zarządzania granicami zewnętrznymi UE. Wnioski wskazują także, że pomimo rozbudowywanych kompetencji wspierania zarządzania granicami na poziomie ponadnarodowym, nadal jest to kompetencja państw członkowskich, dla których nadzór granic lądowych i morskich jest sprawą priorytetową bezpieczeństwa.
\end{abstract}

Słowa kluczowe: Frontex; Eurosur; przestrzeń wolności, bezpieczeństwa i sprawiedliwości; agencje UE; PWBiS; zintegrowany system zarządzania granicami

\section{Wstęp}

$\mathbf{R}$ ozwój koncepcji przestrzeni wolności bezpieczeństwa i sprawiedliwości wymaga wspólnej troski związanej z zapewnieniem bezpieczeństwa granic zewnętrznych UE. Aby sprostać temu wyzwaniu, przewartościowaniu ulega istota systemu zarządzania granicami na poziomie ponadnarodowym i krajowym. Pomimo że jest to sfera kompetencji państw członkowskich, te w swoich suwerennych uprawnieniach biorą także pod uwagę wspólne rozwiązania i korzystają z instrumentów stworzonych w toku ewoluowania roli i znaczenia agencji Frontex. Ma ona usprawniać i koordynować współpracę między właściwymi służbami państw członkowskich. Systemu nadzoru granic w PWBiS nie należy jednak utożsamiać z uwspólnotowionym podejściem na wzór innych polityk UE.

Artykuł ten jest próbą odpowiedzi na pytanie, czy agencja Frontex jest faktycznie nowym rodzajem instrumentu zarządzania przestrzenią wolności, bezpieczeństwa i sprawiedliwości UE? Aby odpowiedzieć na postawione pytanie badawcze należy rozważyć hipotezę, że to tworzone na poziomie ponadnarodowym narzędzia służące realizacji celów Frontex sprzyjają procesowi uwspólnotowienia systemu zarządzania granicami 
zewnętrznymi UE. Rozważania te pozwolą także rozstrzygnąć, jak ustanowienie Frontex zmienia przepływ kompetencji pomiędzy sferą krajową i ponadnarodową w ramach PWBiS.

\section{Przestrzeń wolności, bezpieczeństwa i sprawiedliwości}

Traktat z Maastricht ustanowił sformalizowaną współpracę międzyrządową w obszarach wymiaru sprawiedliwości i spraw wewnętrznych, choć opisał tylko wspólne obszary zainteresowania, w których współpraca może nastapić w celu osiagnięcia tzw. „,innych celów UE”. Jeśli jednak sprawy wizowe, azylu i imigracji, zostały przeniesione w traktacie amsterdamskim do pierwszego filaru i włączone w sferze decyzyjnej do metody wspólnotowej, to zakres współpracy zasadniczo się zmienił (Ekelund, 2014, s. 105). Stąd, to właśnie traktat z Amsterdamu ustanowił przestrzeń wolności, bezpieczeństwa i sprawiedliwości, która zastapiła obszar współpracy w ramach wymiaru sprawiedliwości i spraw wewnętrznych (WSiSW), oraz uczynił pojęcie „wolności, bezpieczeństwa i sprawiedliwości" celem samym w sobie dla działań UE. Warto także zaznaczyć, że osiagnięciem traktatu z Amsterdamu było włączenie Schengen w ramy Unii Europejskiej, jak również wprowadzenie nowych instrumentów prawnych wzorowanych na instrumentach i doświadczeniach Komisji Europejskiej (Kaunert, Leonard, 2010, s. 145).

Określając trzy wyzwania dla europejskich działań w tym obszarze, ważne wnioski przedstawia Monar. Zauważa on, że domena PWBiS obejmuje funkcje tradycyjnie uważane za główne uprawnienia państwa, które służą zapewnieniu obywatelom bezpieczeństwa wewnętrznego, kontroli terytorium i właściwego funkcjonowania sfery wymiaru sprawiedliwości (Monar, 2010, s. 24-26). W doktrynie należą one do podstawowego usprawiedliwienia działań i legitymizacji funkcji państwa, a zatem jest to obszar, gdzie „suwerenność” jest wysoko ceniona (Sassen, 2015, s. 2-32). Dlatego, np. uwspólnotowienie po traktacie amsterdamskim kwestii imigracji i azylu, a tym samym poddanie ich wspólnotowej metodzie decyzyjnej, było kluczowym momentem dla współpracy UE w dziedzinie zarządzania granicami. Moment ten rozpoczął szereg wspólnych działań państw UE na poziomie ponadnarodowym (Ekelund, 2014, s. 110). Ramy instytucjonalne kreowania polityki w tej dziedzinie koncentrują się zatem na usprawnianiu i koordynacji współpracy między państwami członkowskimi, a nie na uwspólnotowieniu podejścia na wzór innych polityk UE. Stąd trzy główne agencje (więcej: Kaunert, Leonard, Occhipinti, 2013, s. 273-284) ustanowione w tym obszarze polityki tj. Europol ${ }^{1}$, Eurojust $^{2}$ i Frontex ${ }^{3}$, koncentrują się na współpracy i koordynacji funkcji wykonawczych bez bezpośrednich uprawnień operacyjnych (Holzhacker, Luif, 2014, s. 8). Dwa główne filary obecnej i przyszłej polityki granicznej UE mają na celu zapobieganie nielegalnej migracji, intensyfikację współpracy z krajami tranzytowymi oraz krajami pochodzenia migrantów, wzmocnienie wspólnych misji kontroli granic oraz europejskiej agencji Frontex (Klepp, 2010, s. 3).

${ }^{1}$ Europejski Urząd Policji.

2 Europejska Jednostka Współpracy Sądowej.

${ }^{3}$ Europejska Agencja Straży Granicznej i Przybrzeżnej (ang. European Border and Coast Guard Agency) jest agencją UE powstałą na mocy Rozporządzenia Rady (WE) nr 2007/2004. 


\section{Rola agencji w PWBiS i ustanowienie Frontex}

Chcąc zrozumieć dynamiczny rozwój agencji, koniecznym jest spojrzeć na szerszy kontekst polityczny. Rozszerzenie UE o kraje Europy Środkowej i Wschodniej, Cypr i Maltę, nadało dynamiki integracji europejskiej i okazało się kluczowe w reorientacji podejścia do współpracy w zarządzaniu granicami. W wyniku rozszerzenia, poza całą granicą lądową (wschodnią), wspólna polityka musiała uwzględnić dwa nowe wyspiarskie obszary śródziemnomorskie Cypru i Malty. Sytuacja ta stworzyła istotny czynnik determinujący utworzenie agencji, gdyż rozszerzenie UE spowodowało problemy w zarządzaniu tymi odcinkami granic zewnętrznych i ukazało istniejące niedoskonałości dotychczasowego systemu (Ekelund, 2014, s. 110). Uzasadnienie takie wydaje się jednak niewystarczające. Trzeba zauważyć, że rozwój agencji uważany jest także za logiczną kontynuację procesu integracji, a dokładniej zasady swobodnego przepływu osób i towarów w ramach rynku wewnętrznego (Neal, 2009, s. 344).

W związku z powyższym, warto poddać rozwadze pytanie czy czas ustanowienia Frontex był przypadkowy? W tym wypadku branie po uwagę tylko instytucjonalnej teorii racjonalnego wyboru nie wydaje się być właściwym podejściem. Fakt, że Frontex został utworzony w tym samym czasie co inne agencje jest zgodny z socjologicznymi oczekiwaniami podejścia instytucjonalnego (Ekelund, 2014, s. 110). Jednak instytucjonalizm utrzymuje także, że ustanowienie agencji powinno być postrzegane w kontekście historycznym. Konkretne wydarzenia mogą służyć jako krytyczne połączenia, które stymulują i prowadzą dalej rozwój po wyznaczonej ścieżce. W tym kontekście, rzeczywiście czas utworzenia Frontex można wyjaśnić serią takich wydarzeń.

W propozycji Komisji, Frontex miał zmniejszać zjawisko nielegalnej imigracji do UE poprzez rozwijanie zdolności operacyjnych na granicach zewnętrznych. Ponadto podejmując samodzielne analizy i tworząc na ich podstawie zalecenia i priorytety, może przeprowadzać niezapowiedziane kontrole. Co więcej, informacje przekazywane przez Frontex są brane pod uwagę w programowaniu prac Komisji (Andersen, 2014, s. 35). Sytuacja taka powoduje, że kwestie Frontex muszą być również dyskutowane we właściwym kontekście instytucjonalnym. Trzeba pamiętać, że agencja jest jedną z kilku inicjatyw, które zgodnie z Guild (2006) stanowią systematycznie „utwardzane narzędzia kontroli” układu granicznego UE. Autorka wyjaśnia, że oprócz Frontex istnieją istotne i współgrające z zadaniami agencji narzędzia tj. system informacyjny Schengen, wspólna lista państw trzecich, których obywatele potrzebują wiz, wspólny format i zasady wydania wiz krótkoterminowych, system informacji wizowej oraz nakładane sankcje/ ograniczenia i system wymiany danych - głównie osobowych (Neal, 2009, s. 345).

Warto dodać, że ustanowienie dedykowanej agencji w zakresie kontroli granic zewnętrznych oraz prowadzenie znacznej liczby operacji policyjnych, zarówno na granicach lądowych i morskich, to kluczowe elementy polityki wzmożonego nadzoru granicznego. Wpisuje się to $\mathrm{w}$ szerszy kontekst eksterytorializacji kontroli migracji. Zintegrowane zarządzania granicami zewnętrznymi, w kontekście migracji i azylu, dla części badaczy utożsamiane jest jednak z budowaniem „twierdzy Europa”, co w argumentacji tej staje się coraz bardziej oddzielone od idei Europy odpowiedzialności, solidarności i partnerstwa. Chociaż do aspektu zabezpieczania granic dodano elementy operacji przechwytywania i dywersji, ich celem jest głównie zwalczanie nielegalnej imi- 
gracji i dążenie do ograniczenia liczby imigrantów i azylantów, którzy chcieliby dostać się do państw UE. Z drugiej strony, analizując ten złożony aspekt, należy dodać, że operacje te zostały wprowadzone także w celu realizacji zadań humanitarnych, ponieważ mogą one potencjalnie zapobiegać wypadkom na morzu (Marin, 2014, s. 80-81).

Warto jednak zauważyć, że Thielemann i El-Enany poddali analizie merytoryczne podstawy z obszaru polityki ochrony uchodźców. Angażują się w sprawę tzw. „twierdzy Europa", której przeciwdziałają i którą odrzucaja, sugerując, że państwa członkowskie były przede wszystkim zainteresowane przezwyciężaniem problemów związanych ze wspólnymi działaniami. Ich zdaniem jest to kluczowy czynnik dla współpracy UE w tej dziedzinie. Tezę weryfikowano, analizując przepisy azylowe UE oraz porównując je $\mathrm{z}$ wynikami w podobnych krajach rozwiniętych spoza UE. Wyniki tego badania sugerują, że nie ma żadnych dowodów na poparcie twierdzenia, że współpraca europejska doprowadziła do wyjątkowo restrykcyjnej polityki migracji i ochrony uchodźców (Kaunert, 2010, s. 147).

Co ciekawe, głównym punktem dyskusyjnym podczas inicjowania działania agencji Frontex nie była legitymacja podejmowanych nagle środków bezpieczeństwa, w którą uposażono agencję. Okazało się, że emocje budził nadzór nad nowopowstającym podmiotem sfery instytucjonalnej UE. Powstał dylemat, która instytucja UE powinna sprawować jurysdykcję nad kwestiami kontroli granic zewnętrznych. Chociaż podkreślano na każdym etapie i w każdej z instytucji, że granice pozostaną odpowiedzialnością państw członkowskich, to Frontex jako agencja UE miał być przykładem przesunięcia od wcześniejszego podejścia międzyrządowego do idei ponadnarodowego systemu zarządzania granicami (Neal, 2009, s. 342). Postanowiono, że losy agencji nie będą wyłącznie w gestii Komisji, jako to w myśli logiki instytucjonalnej UE powinno być, a Frontex uznany zostanie za sferę przenikania się kontroli międzyrządowej i ponadnarodowej. Stąd zarząd agencji składa się z dwóch urzędników KE oraz szefów krajowych służb straży granicznej. Rozwiązanie takie jest dość nietypowe dla agencji UE. Jest to wynik przetargu politycznego, w którym ponadnarodowa wizja Parlamentu Europejskiego nie zdominowała debaty, a Komisja nie chciała w tak „,kontrowersyjny” sposób ingerować w suwerenności państw członkowskich (Neal, 2009, s. 343).

Przechodząc do istoty funkcjonowania agencji, do głównych zadań Frontex należy zaliczyć koordynację współpracy operacyjnej między państwami członkowskimi oraz wsparcie państw członkowskich w sytuacjach wymagających zwiększonej pomocy technicznej i operacyjnej na granicach zewnętrznych, biorąc pod uwagę, że niektóre sytuacje mogą wiązać się z pomocą humanitarną i ratownictwem na morzu. Dodatkowo pomoc państwom członkowskim w sytuacjach wymagających zwiększonej pomocy technicznej i operacyjnej, zwłaszcza gdy dany kraj musi zmierzyć się z nieproporcjonalną presją na swoich granicach zewnętrznych. Istotne jest także wsparcie oraz zapewnienie koordynacji w organizacji wspólnych działań dotyczących powrotów (Marin, 2014, s. 83). Te są uruchamiane w sytuacji, w której państwa członkowskie UE wymagają dalszej pomocy technicznej i operacyjnej na granicach zewnętrznych, w myśl zasady sprawiedliwego podziału kosztów. W sumie wydatki na wspomniane działania stanowią ok. $60 \%$ całkowitego budżetu agencji (Hernández i Sagrera, 2014, s. 172). Dodatkowo rozmieszczenie funkcjonariuszy straży granicznej z europejskich zespołów straży granicznej w ramach wspólnych operacji, projektów pilotażowych lub szybkich interwencji zgodnie z regula- 
cjami w sprawie ustanowienia RABIT (Marin, 2014, s. 83). W tym miejscu warto dodać, że rozporządzenie ws. RABIT upoważnia członków tych zespołu do noszenia broni służbowej, amunicji i sprzętu, i zezwala na ich używanie zgodnie z prawem obowiązującym w państwie, w którym przeprowadzane są działania (Marin, 2014, s. 84). Oprócz podstawowych funkcji w wymiarze operacyjnym, inne zadania agencji jakie warto wskazać to pomoc w szkoleniach krajowych funkcjonariuszy straży granicznej, w tym w ustanowieniu wspólnych standardów szkoleniowych, jak również przeprowadzanie analiz ryzyka, w tym oceny zdolności państw członkowskich do sprostania zagrożeniom i presji na granicach zewnętrznych. Dodatkowo wyróżnić można udział w rozwoju badań mających znaczenie dla kontroli i ochrony granic zewnętrznych (Marin, 2014, s. 83).

Aby realizować postawione przed agencją cele, założono, że Frontex będzie przykładem agencji regulacyjnej z uprawnieniami do podejmowania niezależnych, samodzielnych decyzji (Rozporządzenie nr 2007/2004, art. 25). Cały czas to jednak państwa członkowskie UE posiadają uprawnienia wykonawcze w zakresie zarządzania granicami. Stąd rozporządzenie ustanawiające Frontex potwierdza to stwierdzając, że „odpowiedzialność za kontrolę i ochronę granic zewnętrznych spoczywa na krajach członkowskich" (Rozporządzenie nr 2007/2004, art. 1.2). Agencja działa zatem na poziomie operacyjnym koordynując działania straży granicznych państwa UE (Hernández i Sagrera, 2014, s. 172).

W praktyce zatem spełnia kilka ról, a te nie są zgodne tylko z jedną, nadrzędną logiką. Z jednej strony jej zakres operacyjny zależy w dużej mierze od koncepcji „ryzyka”, która jest podzielona następnie na funkcje oceny ryzyka, które są skierowane nie tylko na „zagrożenie” przepływami migracyjnymi, ale także na zdolności zarządzania granicami i same praktyki stosowane przez państwa członkowskie. $Z$ drugiej strony, agencja dysponuje dostępnymi dla państw członkowskich narzędziami, które mogą zostać użyte w odpowiedzi na nagłe „sytuacje awaryjne” (Neal, 2009, s. 347).

Idąc w rozważaniach dalej, rola regulacyjna Frontex jest częściowo zawarta we „wspólnym zintegrowanym modelu analizy ryzyka” (CIRAM) i jego modus operandi. Warto zauważyć, że częstotliwość występowania pojęcia „ryzyko” jest jednym z bardziej intrygujących aspektów działania agencji. Wydaje się stanowić przesunięcie od podejścia politycznego w kwestiach zagrożenia bezpieczeństwa na rzecz spokojniejszego i bardziej technokratycznego. Dzięki temu rozwój modelu analizy ryzyka ma na celu zapewnienie UE i jej państwom członkowskim odpowiednich informacji pozwalających na podjęcie właściwych do sytuacji działań (Neal, 2009, s. 348). Stąd z jednej strony, Frontex jest agencją regulacyjna, która rozwija środki technologiczne i biurokratyczne w celu harmonizacji zarządzania granicami zewnętrznymi UE i ich kontroli, które w pewnym stopniu reprezentują przeciwieństwo sekurytyzacji. $Z$ drugiej strony, Frontex jest agencją ds. granic zewnętrznych, która często na prośbę państw członkowskich zostaje uwikłana w dyskurs, który ma na celu wyraźne rysowanie linii podziału pomiędzy sferą ponadnarodową a międzyrządową (Neal, 2009, s. 350).

Pomimo powyższych uwag, należy wrócić do punktu wyjścia rozważań zawartych w tym artykule, czyli do założenia, że kontrola granic zewnętrznych UE jest w gestii państw członkowskich (Ekelund, 2014, s. 101), a utworzenie Frontex jedynie ewolucyjnie zmienia ten stan. Zauważa się jednak, że delegacja uprawnień na poziom ponadnarodowy agencji pozwala m.in. na korzystanie ze zgromadzonej w niej wiedzy 
technicznej. Zwiększa to efektywność tej sfery polityki bezpieczeństwa i zarządzania w pewnym sensie ograniczonymi zasobami. Delegacja jest także sposobem na zapewnienie wiarygodnego i stałego zaangażowania we wspólną politykę poprzez zmniejszenie odpowiedzialność za jej funkcjonowanie polityków wybieranych w wyborach powszechnych. W perspektywie instytucjonalnego, racjonalnego wyboru spodziewa się zatem, że Frontex został utworzony w celu obniżenia transakcyjnych kosztów politycznych. Dodatkowo poprzez zatrudnianie ekspertów i stałe rozwijanie wyspecjalizowanej wiedzy, która jest następnie udostępniana decydentom, Frontex ewolucyjnie zmniejsza asymetrię informacyjną w dedykowanej mu sferze polityki bezpieczeństwa (Ekelund, 2014, s. 102-103).

Takle (2012) zainspirowana analizą zmienionego podejścia w kwestii granic, zdefiniowała europejski system kontroli granicznej poprzez połączenie trzech cech. Po pierwsze, można zaobserwować zwiększoną harmonizację głównych kategorii wśród państw strefy Schengen. Oznacza to, że państwa członkowskie stosują te same kryteria wobec osób, którym pozwalają na przebywanie na terytorium strefy, a dodatkowo funkcjonuje złożony systemem kategorii osób, do których odnoszą się różne formy ograniczenia/wykluczenia z możliwości wjazdu i przebywania w UE. Po drugie, wzrasta wykorzystanie nowych technologii i systemów baz danych z otwartym, ale też limitowanym dostępem dla wielu organów UE i służb państw członkowskich w całym zakresie działań w ramach PWBiS. Łączy to ściśle kontrolę z działaniem komunikacji cyfrowej, która nie podlega ograniczeniom geograficznym. Po trzecie, doświadczamy rosnącego sortowania dostępu osób fizycznych do terytorium UE i strefy Schengen co podyktowane jest kwestiami bezpieczeństwa (Takle, 2012, s. 282).

\section{Instrumenty realizacji zadań Frontex - praktyczne podejście}

Zakreślając aspekty praktycznej realizacji zadań Frontex, warto zaznaczyć rozumienie terminu ,granica” w UE. Jedna z podstawowych idei Schengen, czyli rozciagnięcie kontroli granicznych na terytorium całego państwa oraz wypracowanie nowej definicji wspólnych granic zewnętrznych UE, znajduje odzwierciedlenie w Kodeksie granicznym Schengen. Zgodnie z kodeksem, granice zewnętrzne oznaczają granice lądowe państw członkowskich, w tym na rzekach i jeziorach oraz granice morskie, porty lotnicze, porty rzeczne, porty morskie i porty na jeziorach, pod warunkiem że nie stanowią one granic wewnętrznych (zob. Huysmans, 2006; van Munster, 2009). Takie podejście wymagało wypracowania niestandardowych możliwości wspólnego działania i reagowania. Warto zauważyć, że istnieje zauważalna różnica między niekontrowersyjnym charakterem podstawowych zadań agencji, a zadaniami wymagającymi podjęcia bezpośredniego ryzyka. Działania związane z pilną i szybką odpowiedzią zostały dodane przez państwa członkowskie do zadań agencji i zinstytucjonalizowane 11 lipca 2007 roku, gdy Parlament i Rada zmieniły rozporządzenie dot. FRONTEX w celu ułatwienia tworzenia zespołów szybkiej interwencji na granicy (Rozporządzenie nr 1168/2011). Pierwsze szkolenia RABIT i ćwiczenia odbyły się na granicy słoweńsko-chorwackiej w dniu 10 kwietnia 2008 roku. Brali w nich udział funkcjonariusze straży granicznej z 20 państw członkowskich, którzy przeprowadzali kontrole w ramach nadzoru obszarów przygranicznych 
w ramach fikcyjnego scenariusza ,szlaku bałkańskiego" z dużym natężeniem nielegalnej migracji (Neal, 2009, s. 350).

Ponadto na mocy rozporządzenia RABIT, Parlament Europejski i Rada ustanowiły mechanizm tworzenia zespołów szybkiej interwencji na granicy o szerokich uprawnieniach organów ścigania, których celem jest wspieranie państw członkowskich w obliczu nadmiernego przepływu nielegalnych imigrantów. Na wniosek państwa członkowskiego znajdującego się w sytuacji nagłej i wyjątkowej presji, agencja może oddelegować na ograniczony okres jeden lub więcej zespołów szybkiej interwencji na terytorium wnioskującego państwa członkowskiego. W przeciwieństwie do innych operacji Frontex, te są oparte na koncepcji tzw. obowiązkowej solidarności. Oznacza to, że państwa członkowskie są zobowiązane do uczestnictwa. Warto również podkreślić, że jest to rzeczywista kompetencja i rola agencji, gdzie decyzja podejmowana jest przez jej dyrektora wykonawczego. Kwestie finansowania i wyposażenia zespołu są realizowane na poziomie ponadnarodowym, a podczas pracy członkowie zespołu noszą opaskę z insygniami UE. Zostało to zinterpretowane jako ,istotne odejście od tradycyjnej i wyłącznej kompetencji państw członkowskich". Zaznacza się jednak, że w każdym przypadku członkowie zespołów ,pozostają nadal funkcjonariuszami krajowej straży granicznej swoich rodzimych państw członkowskich” (Rozporządzenie nr 863/2007, art. 7) i mogą wykonywać zadania i korzystać z uprawnień w świetle przepisów prawa państwa przyjmującego, i co do zasady, w obecności straży granicznej przyjmującego państwa. W maju 2007 roku uruchomiono na południowych granicach morskich europejskie sieci patroli (EPN), co jest elementem stałej koncepcji bezpieczeństwa granic regionalnych, które umożliwiają synchronizację środków krajowych państw członkowskich UE oraz ich integrację we wspólne działania europejskie (Papastavridis, 2010, s. 78).

Chcąc wskazać najważniejsze instrumenty używane przez organy UE, które chronią PWBiS i wpływają na jej system zarządzania, należy wymienić Europejski system nadzoru granic (ang. The European Border Surveillance System - Eurosur). Jest to element europejskiego systemu kontroli granicznej, który opiera się na stopniowej modernizacji krajowych systemów nadzoru. Głównym celem jest zapobieganie nieautoryzowanemu przekraczaniu granicy, bieżące monitorowanie transgranicznych ruchów migracyjnych, prowadzonych działań przeciwko przestępczości oraz stworzenie wspólnego środowiska wymiany informacji między właściwymi organami krajowymi (Rozporządzenie nr 1052/2013). Dodatkowe wsparcie udzielane jest osobom, które przekroczyły granicę nielegalnie, będąc ofiarami handlu ludźmi (Takle, 2012, s. 288).

Eurosur jest $\mathrm{w}$ istocie systemem wymiany informacji, który umożliwia dzielenie się nimi w czasie rzeczywistym. Udostępnione dane mogą składać się z informacji dotyczących wypadków na zewnętrznych granicach lądowych i morskich UE, statusu i pozycji patroli i małych statków, jak również raportów analitycznych i wywiadowczych (na przykład na zmienionych trasach migracyjnych) lub nowych metodach stosowanych przez handlarzy ludźmi lub narkotyków. Dane te są następnie wykorzystywane do ustalenia zdjęć sytuacyjnych na szczeblu krajowym i europejskim, a także przygranicznego szkicu sytuacyjnego (Rijpma, Vermeulen, 2015, s. 454).

To Frontex jako dotychczasowe centrum gromadzące, przetwarzające i wymieniające dane interoperacyjne dostarcza niezbędnej pomocy w rozwoju i funkcjonowaniu europejskiego systemu nadzoru granic. Agencja otrzymała również zadanie opracowa- 
nia i uruchomienia systemów informatycznych, które umożliwią płynną i niezawodną wymianę informacji dotyczących pojawiających się zagrożeń na granicach zewnętrznych $\mathrm{w}$ tym interoperacyjności systemów (Marin, 2014, s. 84). Za podstawowe zadanie pierwszej fazy funkcjonowania Eurosur należy zatem uznać powiązanie i usprawnienie systemów nadzoru państw członkowskich. Zgodnie z zaleceniami raportu MEDSEA, Narodowe Centra Koordynacji (ang. National Coordination Centres - NCC's) zostają ulepszone (krok 1), podobnie jak krajowe systemy nadzoru (krok 2). Etap 3 przesuwa działania poza granice UE, skupiając się na otoczeniu zewnętrznym. W tym podejściu sąsiednie kraje trzecie będą wspierane w rozwijaniu ich infrastruktury nadzoru granicznego w zgodzie $\mathrm{z}$ całościowym podejściem do spraw migracji. Zbliży to kraje trzecie do zasad europejskiej polityki migracyjnej, czyniąc z nich możliwie „równorzędnych partnerów" w zarządzaniu przepływami migracyjnymi (Rijpma, Vermeulen, 2015, s. 460).

Drugi etap jest relatywnie nowy i dotyczy usprawnienia oraz rozwoju wspólnych narzędzi służących do nadzorowania granic na poziomie UE. Komisja zaleciła, aby siódmy ramowy program badawczy był wykorzystany do stymulowania sfery badań i rozwoju m.in. satelit i samolotów bezzałogowych (w tym dronów), które mogą zostać wykorzystane do monitorowania obszarów „zewnętrznych" (takich jak otwarte morze czy wybrzeża), a w wyjątkowych sytuacjach także terytoriów państw trzecich. Wdrożenie tych narzędzi pozwoli FRONTEX efektywniej zbierać informacje strategiczne służące „rozpoznaniu wzorców i analizowaniu zachodzących trendów”. Mogą one posłużyć do stworzenia wspólnego obrazu sytuacyjnego przedpola granic, opartego także w części na danych wywiadowczych. Będzie to kolejny element wspierający Frontex w ramach koordynacji działalności operacyjnej krajowych centrów sytuacyjnych (Rijpma, Vermeulen, 2015, s. 460).

W celu realizacji wspólnego mechanizmu wymiany informacji, trzecia faza łączy ze sobą wyniki poprzednich oraz stworzy nadbudowę nad dotychczasowymi systemami integrującą wszystkie istniejące systemy, które służą raportowaniu i monitorowaniu ruchu i działań na obszarach morskich znajdujących się pod jurysdykcją państw członkowskich oraz na przyległych morzach. Według Komisji, stworzenie tak zintegrowanej sieci systemów obserwacji dla celów bezpieczeństwa wewnętrznego na południowych i wschodnich granicach morskich należy uznać za inicjację wspólnego mechanizmu wymiany informacji dla całego obszaru morskiego UE obejmującego wszystkie aspekty bezpieczeństwa morskiego. Na koniec tego wątku warto wskazać, że Komisja po raz pierwszy uznała, iż działania Eurosur mogłyby również wiązać się z przetwarzaniem danych osobowych. (Rijpma, Vermeulen, 2015, s. 460).

Frontex pełni centralną rolę w funkcjonowaniu Eurosur, co czyni go odpowiedzialnym za utrzymanie sieci informacyjnej. Na podstawie własnych danych i danych z NCC (tzw. krajowy obraz sytuacyjny), agencja monitoruje stan rzeczywisty na granicach zewnętrznych UE, a także tworzony jest obraz sytuacyjny bliskiej przygranicy. Taki podgląd sytuacyjny sugeruje decydentom w agencji o poziomie oddziaływania (niskim, średnim i wysokim) konkretnego wydarzenia na stan bezpieczeństwa wskazanych odcinków lądowych i morskich. W zależności od poziomu oddziaływania państwa członkowskie byłyby zobowiązane do poprawy ich zdolności reagowania poprzez intensyfikację swoich działań nadzorczych, co ewentualnie może się odbywać przy pomocy Frontex. Agencja z kolei powinna podejmować działania zmierzające do dalszego ułatwienia wspólnego 
stosowania narzędzi nadzoru, takich jak wykorzystania satelit i bardziej zaawansowanych systemów raportowania statków (Rijpma, Vermeulen, 2015, s. 462).

Warto także zauważyć, że Eurosur jest ściśle powiązany z dwoma programowanymi długoterminowo procesami UE. Z jednej strony z rozwojem europejskiej koncepcji zarządzania granicami, a z drugiej tzw. holistycznego podejścia do spraw migracji i mobilności. Trzeba zauważyć, że sytuacja migracyjna na południowych granicach (morskich) wpłynęła znacząco na rozwój polityki w zakresie zarządzania granicami zewnętrznymi oraz całościowego podejścia (Rijpma, Vermeulen, 2015, s. 455).

Interesujące jest jednak, że jeśli przyjmie się założenie, iż ratowanie życia na morzu to tylko jeden z celów Eurosur, to powstaje dylemat, jak należy zakwalifikować wspominany „system systemów”? Musiałby on zostać uznany za model organizacyjny, który jest zdolny do przekształcenia sposobów, w jaki władze krajowe poprzez państwowe straże graniczne reagują na zagrożenia, a także w jaki sposób straże te są zorganizowane. To pokazuje potencjał transformacyjny działań Frontex na współpracę operacyjną między organami administracji krajowych a agencją. Dzięki Eurosur zarządzanie granicami zewnętrznymi na poziomie państw szybciej ewoluuje, dokonując pozornie oddolnej integracji, która w rzeczywistości jest definiowana i podjęta na poziomie europejskim (Rijpma, Vermeulen, 2015, s. 468).

Prawdą jest, że Frontex nie może instruować państw członkowskich w jaki sposób reagować na informacje z systemu Eurosur, ale będzie z pewnością w stanie wywierać wpływ, aby konkretne działania zostały na poziomie kraju podjęte. Co więcej, rozporządzenie dot. Eurosur nie zobowiązuje także państw członkowskich do zgłaszania incydentów, jak również Frontex nie sprawuje kontroli nad jakością umieszczanych danych. Biorąc jednak pod uwagę stopniowy rozwój europejskiego systemu zarządzania granicami i ciągłe wzmacnianie pozycji agencji, wydaje się kwestią czasu, zanim te punkty będą rozpatrywane. W komunikacie Komisji dotyczącym oddziałów specjalnych na Morzu Śródziemnym już wzmocniono potencjał Eurosur i zintensyfikowano współpracę oraz współdziałanie między Frontex a Europejską Agencją do spraw Bezpieczeństwa na Morzu (EMSA). Szczególne znaczenie ma dalsze rozwijanie możliwości technicznych dotyczących nadzoru granic, a w szczególności aspektów związanych z wykrywaniem małych statków (Rijpma, Vermeulen, 2015, s. 468).

Oprócz postępującej europeizacji zarządzania zewnętrznymi granicami strefy Schengen, Unia Europejska poprzez współpracę praktyczną i technologiczną w ramach Eurosur potwierdza także inne, długo istniejące w przestrzeni wolności, bezpieczeństwa i sprawiedliwości trendy w zakresie azylu i migracji. Pierwszy, silny wymiar zewnętrzny tego obszaru polityki to próba związania krajów trzecich, ale raczej jako ,strażników UE” i współgwarantów skutecznej realizacji założeń systemu. Warto zauważyć, że współpraca ta nie jest jednak realizowana na obopólnie korzystnym partnerstwie, a ma skutkować przesunięciem elementów zabezpieczających granice UE poza rzeczywistą linię graniczną państw członkowskich. Niewątpliwie współpraca państw trzecich w ramach Eurosur zostanie nagrodzona np. wsparciem finansowym i technicznym, ale jest mało prawdopodobne, że ograniczające dla obywateli państw trzecich skutki Eurosur lub jakiegokolwiek innego środka kontroli zostaną przesunięte w najbliższej przyszłości w stronę znacznego rozszerzenia polityki legalnej migracji. Po drugie widoczny jest trend w kierunku cyfryzacji granic oraz poleganiu na danych i wymianie informa- 
cji. Chociaż Eurosur nie jest samą bazą i będzie przetwarzać tylko ograniczone zasoby danych osobowych, mechanizm ten należy jednak postrzegać w świetle podobnych inicjatyw, które zasadniczo dehumanizują granice poprzez wykorzystanie technologii. Przykładem są „Smart Borders”, system wejścia-wyjścia oraz Traveller Programmes (Rijpma, Vermeulen, 2015, s. 469).

\section{Zintegrowane zarządzanie granicami}

Warto wspomnieć, że KE była od początku świadoma niechęci państw członkowskich w kwestii rozszerzania integracji w tej sferze. Stąd IBM (ang. Integrated Borders Management) zmierza do podejmowania kluczowych decyzji wspólnie, aby lepiej koordynować działania operacyjne w ramach zintegrowanej strategii. Trzeba pamiętać, że koncepcja IBM jest skoordynowana z zasadami Kodeksu granicznego Schengen i ma wspierać wykrywanie przestępczości transgranicznej oraz współpracę między właściwymi organami państw członkowskich także na poziomie ponadnarodowym (Hernández i Sagrera, 2014, s. 170). IBM jest szerzej związany z rozwojem strategii bezpieczeństwa wewnętrznego UE (Wolff, 2010, s. 26). Podkreśla się, że zarządzanie granicami zewnętrznymi strefy Schengen musi być zintegrowane i musi dotyczyć wszystkich możliwych zagrożeń (Carrera, 2007, s. 3) wskazanych w kolejnych europejskiej strategiach bezpieczeństwa. IBM legitymizuje i wzmacnia praktyki bezpieczeństwa na zewnętrznych granicach UE (Carrera, 2007, s. 27). Poza tym, zgodnie z Kodeksem granicznym Schengen, cele tj. promowanie IBM oraz „wzmacnianie bezpieczeństwa” są ze sobą powiązane. Podobnie stanowi Komisja, gdyż już w programie sztokholmskim, który określał program działań w dziedzinie sprawiedliwości i spraw wewnętrznych w latach 2009-2014, zdefiniowano IBM jako ,politykę służącą zwalczaniu nielegalnej imigracji”. Wraz z traktatem z Lizbony pojęcie IBM zostało wprowadzone do prawa pierwotnego UE. W związku z tym Parlament Europejski i Rada mogą regulować przepisy prawne w tej sferze (Hernández i Sagrera, 2014, s. 170). Bardziej precyzyjnie, traktat ustanawia, że UE powinna opracować politykę mającą na celu stopniowe wprowadzanie zintegrowanego systemu zarządzania granicami zewnętrznymi (Traktat z Lizbony, art. 77), czego częściową realizacją stało się także wprowadzenie m.in. Eurosur.

Koncepcja IBM nie pozostaje jednak wolna od krytyki. Pojawiają się głosy, że technologia i nowe rozwiązania techniczne nie mogą być główną odpowiedzią na pojawiające się problemy i zagrożenia bezpieczeństwa wewnętrznego. Braki w koncepcji IBM zostały również podkreślone przez Monara, który zauważa, że zintegrowany system cierpi z powodu ograniczeń. Po pierwsze, nadal istnieje deficyt w sferze koordynacji i ewaluacji działań. Następnie problematyczne są ograniczenia wynikające z braku transgranicznych uprawnień organów ścigania odnoszących się do straży granicznej (Hernández í Sagrera, 2014, s. 171). Niedawne zaangażowanie w regionie Morza Śródziemnego w następstwie kryzysów w krajach Afryki Północnej i Bliskiego Wschodu oraz rozmieszczenia kolejnych zespołów szybkiej interwencji na granicy (RABIT), było krytykowane przez organizacje zajmujące się ochroną praw człowieka. Dodatkowo sytuacje te przyciągają większą niż dotychczas uwagę mediów, co nie zawsze korzystnie wpływa na ich skuteczne rozwiązanie (Ekelund, 2014, s. 100). 


\section{Podsumowanie i wnioski}

Odpowiadając na pytanie, czy agencje UE są nowym rodzajem instrumentu zarządzania PWBiS UE, należy najpierw zauważyć, że Frontex zaproponował rozwiązania zmierzające do skuteczniejszej wymiany doświadczeń i budowania więzi między państwami członkowskimi w sferze bezpieczeństwa granic. Patrząc bardziej szczegółowo na konstrukcję Frontex i przykładowo SCIFA (Strategiczny Komitet ds. Imigracji, Granic i Azylu ), są one kontrolowane w swoich decyzjach strategicznych i operacyjnych przez administracje krajowe w ramach Rady. Obie jednak podlegają także hierarchicznej kontroli, czyli ingerencjom politycznym w ramach funkcjonowania systemu instytucjonalnego UE (Wolff, Schout, 2013, s. 319). Ponadto w temacie zarysowują się dwie główne linie rozważań. Po pierwsze, założenie, że zarządzanie agencją Frontex może się udać tylko wtedy, gdy jednostki niższego szczebla będą posiadały odpowiedni stopień autonomii organizacyjnej w realizacji określonych przez Radę celów oraz posiadać będą stałe wsparcie ze strony państw członkowskich. Drugie założenie jest związane z obawą, w jak sposób dzielony poziom sterowania politycznego agencją i niska legitymacja podejmowanych przez nią autonomicznych decyzji wpływa na odpowiedzialność za podejmowane przez nią działania (Pollak, Słomiński, 2009, s. 906).

Wolff i Schout zauważaja, że transparentność nie jest największym atutem agencji. Trudno jest uzyskać dostęp do części dokumentów Frontex, oprócz ogólnego rocznego raportu i sprawozdania z analizy ryzyka i ustaleń roboczych z krajów trzecich, które są dostępne. Pollak i Słomiński doszli do wniosku, że „Frontex kontynuuje kulturę tajemniczości”. O ile kontrola prawna jest zapewniona, utworzenie agencji nie uregulowało kwestii odpowiedzialności za przeprowadzane operacje. Państwa członkowskie są nadal odpowiedzialne za to, co dzieje się na ich zewnętrznych granicach. Co ciekawe, organizacje pozarządowe wskazują że dochodziło do naruszania prawa międzynarodowego podczas wspólnych operacji (Wolff, Schout, 2013, s. 317).

Pozytywnie należy zweryfikować założenie, że to tworzone na poziomie ponadnarodowym narzędzia służące realizacji celów Frontex sprzyjają procesowi uwspólnotowienia systemu zarządzania granicami zewnętrznymi UE. Trzeba podkreślić, że Frontex kontynuuje kontrolę funkcjonalną, która istniała już w ramach SCIFA+/PCU. Agencja jest w centrum wielu sieci skupiających ekspertów krajowych. Należą do nich analizy ryzyka, sieć szkolenia krajowych grup koordynatorów oraz sieci współpracy Eurosur. Ponadto ustanowiono kontakty z organizacjami międzynarodowymi takimi jak UNHCR, który wysłał starszego oficera łącznikowego do agencji. W aspekcie kontroli administracyjnej uległy poprawie zwłaszcza procedury planowania, jednak aspekt samych operacji jest wciąż niewystarczająco szczegółowo zdefiniowany (Wolff, Schout, 2013, s. 318).

Idąc dalej w podsumowaniach, znaczenie nadzoru granicznego Frontex i jego rola w rejonie Morza Śródziemnego dotyczyły samych działań przechwycenia i dywersji (HERA), asystowaniu przy nich (Nautilus) oraz współpracy z władzami krajowymi w celu ujęcia nielegalnych migrantów i przesyłania ich do specjalnych ośrodków w celu ich readmisji. Należy także dodać wywiady z migrantami w celu określenia ich narodowości, co funkcjonowało nieraz bez właściwego informowania imigrantów o przysługujących im prawach (działania RABIT czy Posejdon). Wszystkie te przypadki pokazują, że Frontex przyjął szerokie podejście do nadzoru granicznego wraz z jednostronną in- 
terpretacją jego misji i niepełnego zastosowania prawa azylowego (Marin, 2014, s. 88). Szeroka interpretacja zakresu nadzoru granic dzięki omawianym już ramom prawnym i kontroli legalności działań dały agencji znaczną autonomię przy dyskusyjnej w literaturze odpowiedzialności (Marin, 2014, s. 86).

Rozstrzygając założenie, że ustanowienie Frontex zmienia przepływ kompetencji pomiędzy sferą krajową i ponadnarodową w ramach PWBiS i powracając do punktu wyjściowego rozważań podjętych w tym artykule, zaznaczone zostało, że pomimo rozbudowywanych kompetencji wspierania zarządzania granicami na poziomie ponadnarodowym, cały czas są to kompetencje państw członkowskich, dla których nadzór granic lądowych i morskich jest sprawą priorytetową bezpieczeństwa. Przykład grecki pokazuje, że działania te wymagają ścisłej współpraca greckiej policji i straży przybrzeżnej z innymi organizacjami, a także $\mathrm{z}$ jednostkami posiadającymi radary monitorujące powierzchnię, w tym z jednostkami morskiego patrolowania na morzu, jak również z obserwacjami prowadzonymi przez wojsko. Może być również konieczne stosowanie innych środków do ochrony granic, takich jak satelity, bezzałogowe samoloty, czy sterowce wyposażone w czujniki. Stąd działania Frontex uzupełnione systemem Eurosur wpisują się płynnie w te dążenia (Korontzis, 2012, s. 196).

Warto także zauważyć, że połączenie elementów europejskiego reżimu kontroli granicznej na wcześniej rozproszonych obszarach polityki zaciera się. Oznacza to, że polityka w zakresie kontroli granicznej, azylu, imigracji, współpracy sądowej i współpracy policyjnej jest konsolidowana w kompleksowym podejściu. Dodatkowo ewolucja taka wspiera wzmocnienie wspólnej polityki zagranicznej i bezpieczeństwa UE. Pamiętać jednak trzeba, że kombinacja różnych aspektów bezpieczeństwa na różnych szczeblach władzy wymaga koordynacji polityk o zasadniczo różnych celach, co w omawianej sferze niekiedy wykracza poza klasyczne podejście do kontroli granicznej (Takle, 2012, s. 282).

\section{Bibliografia}

Andersen S. (2014), Non-Binding per Evaluation within an Area of Freedom, Security and Justice Ronald, w: Freedom, Security and Justice in the European Union - Internal and External Dimensions of Increased Cooperation after the Lisbon Treaty, red. L. Holzhacker, P. Luif, Springer, New York-London.

Carrera S. (2007), The EU border management strategy: FRONTEX and the challenges of irregular immigration in the Canary Islands, CEPS Working Document no. 261, Centre for European Policy Studies, Brussels.

Ekelund H. (2014), The Establishment of Frontex: A New Institutional Approach, „Journal of European Integration", vol. 36, nr 2.

Guild E. (2006), Danger - Borders under Construction: Assessing the First Five Years of Border Policy in an Area of Freedom, Security and Justice, w: Freedom, Security and Justice in the European Union: Implementation of the Hague Programme, red. J. de Zwaan, F. Goudappel, AsserPress, The Hague.

Hernández i Sagrera R. (2014), Exporting EU integrated border management beyond EU borders: modernization and institutional transformation in exchange for more mobility?, „Cambridge Review of International Affairs", vol. 27, nr 1.

Holzhacker R. L., Luif P. (2014), Introduction: Freedom, Security and Justice After Lisbon, w: Freedom, Security and Justice in the European Union: Internal and External Dimensions of In- 
creased Cooperation after the Lisbon Treaty, red. R. L. Holzhacker, P. Luif, Springer, New York-London.

Huysmans J. (2006), The Politics of Insecurity: Fear, Migration and Asylum in the EU, Routledge.

Kaunert Ch., Leonard S., Occhipinti J. D. (2013), Agency Governance in the European Union's Area of Freedom, Security and Justice, ,Perspectives on European Politics and Society”, vol. 14, nr 3.

Kaunert Ch., Leonard S. (2010), After the Stockholm programme: an area of freedom, security and justice in the European Union?, „European security”, vol. 19, $\mathrm{nr} 2$.

Klepp S. (2010), A Contested Asylum System: The European Union Between Refugee Protection and Border Control in the Mediterranean System, „European Journal of Migration and Law”, vol. 12 , nr 1.

Korontzis T. (2012), The Contribution of EUROPOL and FRONTEX in Combating the Phenomenon of Illegal Immigration in Hellas, „Review of European Studies”, vol. 4, $\mathrm{nr} 1$.

Marin L. (2014), Protecting the EU's Borders from Fundamental Rights? Squaring the Circle Between Frontex's Border Surveillance and Human Rights, w: Freedom, Security and Justice in the European Union: Internal and External Dimensions of Increased Cooperation after the Lisbon Treaty, red. R. L. Holzhacker, P. Luif, Springer, New York-London.

Monar J. (2010), The Institutional Framework of the AFSJ: Specific Challenges and Dynamics of Change, w: The Institutional Dimension of the European Union's Area of Freedom, Security and Justice, red. J. Monar, Peter Lang, Brussels.

Neal A. (2009), Securitization and Risk at the EU Border: The Origins of FRONTEX, „Journal of Common Market Studies", vol. 47, nr 2.

Papastavridis E. (2010), 'Fortress Europe' and FRONTEX: Within or Without International Law?, „Nordic Journal of International Law”, vol. 79, nr 1.

Pollak J., Slominski P. (2009), Experimentalist but not accountable governance? The role of Frontex in managing the EU's external borders, „West European Politics”, vol. 32, nr 5.

Rijpma J., Vermeulen M. (2015), EUROSUR: saving lives or building borders?, „European Security”, vol. 24, nr 3 .

Rozporządzenie Rady (WE) nr 2007/2004 z dnia 26 października 2004 r. ustanawiajace Europejskq Agencję Zarzqdzania Wspótpracq Operacyjnq na Zewnętrznych Granicach Państw Członkowskich Unii Europejskiej, Dz. Urz. L 349 z 25.11.2004 r.

Rozporządzenie Parlamentu Europejskiego i Rady (UE) nr 1168/2011 z dnia 25 października $2011 \mathrm{r}$. zmieniajace rozporzqdzenie Rady (WE) nr 2007/2004 ustanawiajqce Europejska Agencje Zarzqdzania Współpracq Operacyjnq na Zewnętrznych Granicach Państw Członkowskich Unii Europejskiej, Dz. Urz. L 304/1 z 22.11.2011 r.

Rozporządzenie Parlamentu Europejskiego i Rady (WE) nr 863/2007 z dnia 11 lipca 2007 r. ustanawiajace mechanizm tworzenia zespołów szybkiej interwencji na granicy oraz zmieniajace rozporzadzenie (WE) nr 2007/2004 Rady w odniesieniu do tego mechanizmu i określajace uprawnienia i zadania zaproszonych funkcjonariuszy, Dz. U. L 199 z 31.07.2007 r.

Rozporządzenie Parlamentu Europejskiego i Rady (UE) nr 1052/2013 z dnia 22 października 2013 r. ustanawiajace europejski system nadzorowania granic (EUROSUR), Dz. Urz. L 295 z 6.11.2013 r.

Sassen S. (2015), Losing Control - sovereignty in an age of globalization, Columbia University Press, New York.

Takle M. (2012), The Treaty of Lisbon and the European Border Control Regime, „Journal of Contemporary European Research", vol. 8, nr 3.

Traktat z Lizbony zmieniający Traktat o Unii Europejskiej i Traktat ustanawiający Wspólnotę Europejska, Dz. Urz. C 306 z 17.12.2007 r.

van Munster R. (2009), Securitizing Immigration: The Politics of Risk in the EU, Palgrave Macmillan, London. 
Wolff S. (2010), EU integrated border management beyond Lisbon: contrasting policies and practice, w: Shaping the normative contours of the European Union: a migration - border framework, red. R. Zapata-Barrero, CIDOB, Barcelona.

Wolff S., Schout A. (2013), Frontex as Agency: More of the Same?, „Perspectives on European Politics and Society", vol. 14, nr 3.

\title{
The managing role of Frontex within the Area of Freedom, Security and Justice of the EU
}

\begin{abstract}
Summary
The aim of the article is a horizontal and functional analysis of the positioning of the Frontex agency in the EU's institutional architecture and its significance in the emerging supranational system of securing the EU's borders. This article attempts to answer the question of whether Frontex is a new type of instrument for managing the EU's area of freedom, security and justice (AFSJ). The study applies qualitative methods, and the source of information was provided by an analysis of the content of the documents and the literature on the subject.

The article presents the role and specific features of supranational agencies, the importance of Frontex and its positioning in the EU's institutional structure, as well as the instruments created to achieve the agency's objectives, i.e. Eurosur and IBM. The issue of national and supranational spheres overlapping with respect to the AFSJ is also discussed.

The article argues that the assumption that the tools created at the supranational level to achieve Frontex's objectives foster the process of communitarization of the EU's external border management system should be confirmed. The conclusions also demonstrate that despite extending the competences to support border management at the supranational level, it is still the competence of member states, who consider the surveillance of land and sea borders to be the foremost security matter.
\end{abstract}

Key words: Frontex; EUROSUR; Area of freedom, security and justice; EU's agencies; AFSJ; Integrated Borders Management 